\title{
Infringement Cases of Intellectual Properties
}

\author{
Faith Caiudo Orillaza, MBA student
}

faith.orillaza@westcliff.edu

\begin{abstract}
Intellectual properties are collected ideas and concepts that originated from different sources, such as an individual or company. The entity who carries the title of being the owner of the idea has the sole right in copying or duplicating his own concepts. Despite entitlement of ownership, many people step across the perimeter of the boundaries set by the author. This type of violation is called copyright infringement, where ideas are copied and used without the approval of the originator. The focus of this paper is to discuss some of the companies who are involved in infringement issues like Napster, Bertelsmann, and Blackberry. They were sued by Metallica, Electric and Musical Industries (EMI) and Universal Studios respectively. Additionally, making use of one's invention without the permission of the inventor is called patent infringement. It violates the exclusive rights given by the federal government to the maker of the innovation. NTP Inc., a company with no technology of its own and Oxbo both violated patent rights and were sued by Research in Motion (RIM) and H\&S Manufacturing respectively. Each of these cases will be discussed in detail considering various facts, violations, court rulings, and financial damages.
\end{abstract}




\section{Introduction}

All types of violations in the United States have corresponding punishments. Stealing of intellectual property, which belongs to the originator, is a crime which falls under copyright infringement or patent infringement. Companies who are accused of this are not spared from being questioned on any infringement offenses. When proven guilty, the company could face losses of millions of dollars in revenue or possibly its entire operation. This happened in the case of Napster, Bertelsmann, and Blackberry when they robbed the intellectual properties of copyright holders like Metallica, Electric and Musical Industries (EMI) and Universal Studios, respectively. In the same way, NTP Inc. and Oxbo used the intellectual properties of Research in Motion (RIM) and H\&S Manufacturing without obtaining the correct permission to do so. Details of the infringement cases faced by these parties are discussed below.

\section{Discussion}

\section{Copyright Infringement Cases- Napster sued by Metallica.}

To give a brief background, Napster turned out to be a well-known company since 1999 on its inception when Shawn Fanning introduced his concept on the Internet. Music collections with MP3 format are easily downloaded. Through Napster, acquiring music files and sharing with a click of a button became easy. In reaction to this, many bands and musicians attempted to sue Napster. One of these bands was Metallica, whose drummer, Lars Ulrich, was the most vocal in attempting to revoke Fanning's idea.

Metallica sued Napster on the occasion when "a leaked recording of the track I Disappear from the Mission: Impossible 2 soundtrack made its way onto Napster, and then onto the radio before its official release" (Patel, 2015, p. 5). Metallica's main complaint is that Napster did not consent them in using their music. Not only that, Napster put in their system the music of Metallica where everyone can freely download it (Patel, 2015).

Certainly, Metallica was very much affected because of copyright infringement. Instead of earning copyright royalties which should have been given to the Mission Impossible production team, the team received nothing, not even a request for them to allow Movie Maker to use their music. Therefore, in April 2000, Metallica sued Napster and in the same year, in the month of October, A\&M sued Napster on the same grounds (Rosoff, 2011). 
Napster defended themselves by citing the 1992 Audio Home Recording Act. The legislation permitted anyone to make digital recordings for private use, but also required the manufacturer of the digital audio tapes machine and the mini-disc recorder to give the royalty fee to the owners of the copyright (Rowell, 2017). Napster contended that they are just catering the needs of private users and make the process simpler which does not violate the law.

Additional words from Napster's side came from their CEO who claimed that they were not copying files. MP3 files were not the creation of Napster. He expressed that Napster was just the facilitator for all the music lovers to talk with each other and share their love of music, as well as sample it. If people were able to sample the music, they could figure out if they would want to buy recordings or recommend them to others (Taro, 2000). The question remains tough, what is the point in purchasing something when it is already free? Bertelsmann sued by EMI and Universal Studios.

A different group under the Recording Industry Association of America (RIAA) sued Napster, which made the latter bankrupt. In this situation, Napster sought financial support from companies such as Bertelsmann. Bertelsmann eventually gave in to the demand of Napster and loaned the company $\$ 85$ million. In effect, they turned out to be involved in the dispute between Napster and different musicians who are filing cases against Napster. Some of these disputes arose from EMI and Universal Studios (Sandoval, 2007).

Bertelsmann tried to prove that their connection with Napster only began in 2001 when they assisted them during Napster's case trials. Bertelsmann claimed that they were not partakers of any illegal matters (Sandoval, 2007). To lend money to Napster does not mean that they are conniving to its criminal affairs (Harmon, 2003). What Bertelsmann saw is the good side that Napster makes improvement in music industry (Kravets, 2009). Indeed, the former showed hope for Napster and considers it a legitimate online music service provider. This is why they decided to provide financial aid, unknowingly digging themselves into the same grave. 


\section{Court rules and financial damages- Napster}

In 2002 a federal judge and court of appeals in San Francisco charged Napster copyright infringement fees because they became the platform where people could download and acquire music of different artists without paying (Kravets, 2009). Napster was required to pay over $\$ 40$ million due to copyright violations.

\section{Bertelsmann}

The court demanded Bertelsmann to pay Universal Music Group \$60 million, Warner Music Group \$110 million, and National Music Publishers Association \$130 million (Kravets, 2009).

Patent Infringement Cases- Research in Motion (RIM) sued by NTP Inc.

First, let me introduce the two companies which are involved in a legal dispute. Research in Motion (RIM) is a Canadian company which began in 1984 and has been successful as the years have gone by. In 1996, it developed a concept to innovate a wireless device and a two-way pager which was handy and could be kept in a pocket. In 1998, Blackberry phones started to support and move voice signals upon starting a contract with Canadian and American telecom companies. In January 1999, Blackberry became more useful for having additional features. The Blackberry device served as a, "phone, pager, e-mail, personal organizer, and web browser" (Weston \& Lim, 2008, p.3). A record states that in 2000, RIM made sixteen patent portfolios, while in 2007 , the figure went up as high as 400 . In this same year, there were 8 million people who used Blackberry.

On the other hand, the late Thomas Campana, Jr. owned NTP Inc., a Virginia based company. The late owner started inventing electronic items in the 1970's. In the 1980's, NTP concentrated on wireless pager technology. In 1992, Thomas Jr. began protecting his inventions and acquired up to fifty patents. While in the process of creating these patents, NTP suffered from bankruptcy.

The issue began in year 2000 when the bankrupt NTP still operated its business by suing different companies who infringed on their patented inventions. NTP did send out warning emails to companies like RIM to warn them that they need to acquire a right to use NTP's 
technology. RIM did not heed this warning. In November 2001, NTP submitted a lawsuit against Blackberry stating that Blackberry infringed upon eight of NTP's patented works.

Blackberry was facing a big issue, during the same period that RIM was flourishing in North America, Europe, and Asia. The revenue of RIM increased by 33\% during this time (Weston \& Lim, 2008). The more RIM's revenue increased, the more NTP saw an opportunity to gain from RIM.

RIM requested to have the issue re-evaluated by the Court. In 2002, the infringement case of RIM went to a US jury trial. RIM presented an old device which they claimed that they created in the courtroom. However, RIM was not able to prove through their demonstration that it was an old enough because the device used the latest technology. On that condition, the judge saw the discrepancy on the part of RIM and thus, did not consider the evidence valid. (Weston, \& Lim, 2008).

In addition to the above, RIM sent a letter to NTP mentioning about the technical manuals of Telenor, a Norwegian Telecom company. The documents presented a wireless device for e-mail messaging. In this scenario, RIM argued that Campana (NTP founder) claimed he invented the patented item in 1990 while the technical manual's publication date was 19861989 (Weston \& Lim, 2008). The arguments brought up by RIM were set aside by the Supreme Court, which made RIM suffer penalties.

H\&S Manufacturing sued by Oxbo International Corporation

Oxbo International Corp is a known American Company which deals with the manufacturing of agricultural equipment. Their engineers work hard for the design and development of their machineries to cater the needs of farmers (EauClaire, 2012). In May 2015, Oxbo sued H\&S Manufacturing for infringing on four of the triple head merger patents they owned (Stich, 2017).

Court rules and financial damages- Research in Motion

On August 5, 2003 the District Court went in favor of NTP and "awarded damages based upon its assessment of the estimated income derived from certain of the Company's revenues that were considered infringing revenues" (Horgan, 2006, p.1). RIM brought the case to a 
higher court. On December 14, 2004 the Court of Appeals supported the judgment of the District Court.

However, in 2005 RIM and NTP made a negotiation. RIM would still operate and "have the right to grant sublicenses under the NTP patents for products or services that interface, interact or combine with RIM's products, services or infrastructure" (Horgan, 2006, p.1). By demanding that RIM pay NTP \$450 million (originally $\$ 612$ million before the negotiation), NTP gave RIM the permission to operate freely without being bothered by any further claim from NTP (Horgan, 2006).

\section{H\&S Manufacturing}

After 2 years, the court's and jury's decisions were tallied. It had been proven that H\&S infringed Oxbo's patents which were identified in the Tri-Flex Window Merger. H\&S was required to pay for damages and was ordered not to make, use, or sell Tri-Flex window mergers in the future (Stich, 2017).

\section{Eventualities/Analysis}

As mentioned above, Napster went bankrupt after it got involved in a lawsuit during an infringement case. However, despite its loss on the cases filed against them, the brand and logos were adopted by Roxio. Napster name was bought for \$5 million by Roxio (Bary, 2005). Hence, Best Buy was about to buy Napster for $\$ 121$ million but since the latter had $\$ 67$ million in cash therefore Best Buy just paid them the remaining balance which is \$54 million (Hansell, 2008). In 2005, Rhapsody was trying to join Napster (Levy, 2005) but only in 2011 when Rhapsody adopted Napster and in 2016 the former relaunched the latter (Popper, 2016).

In the case of Blackberry, there is a nonstop volume of demand on this popular gadget and service while NTP worked hard to ensure that they were heard by the court regarding the infringement case of RIM. Despite the loss of the head of NTP, its body continued to spoil the image of RIM in the market. Consequently, RIM ended up having to pay $\$ 650$ million dollars 
plus other damages to NTP. Blackberry continued its operation but got eventually was surpassed by Apple and Samsung.

Despite Napster's business failure, there are companies who became willing to acknowledge its strength, even using its own name while the tainted brand name was known to all. Essentially, businesses require publicity. Once this element is established, though credibility is ruined, there are establishments who still see the positive effect of restoring a dead business. In doing so, a new horizon awaits, and exciting outcomes are anticipated by these two companies.

With respect to Blackberry, I regret the time when they received a letter from NTP to warn them about the infringement issues that they committed. Upon ignoring the notification, in a matter of a year, they failed to foresee the huge tide which rocked their boat, the stability of their operation. It is good that the billion-dollar company, RIM, remains solid. Otherwise a big blow may have turned been their fate, just like what happened with Napster.

\section{Conclusion}

What a fulfilling feeling when someone is able to discover, invent, compose, and create ideas that no one has ever thought of before. To seal the newly discovered concept or creation, a set of procedures have been established by the government to protect the intellectual property. Imagine if after this there was an intruder, or group of invaders who dove in to steal the concept or enjoy the benefits of utilizing the product for free. That does not seem fair. Therefore, copyright and patent law became crucial to secure owners' inventions and designs. Copyright and patent owners simply need recognition and above all respect and permission. That is all that matters, to avoid any disheartening or dispiriting feelings of the author, whose was the original source of all the ideas that were introduced or imparted to the world to serve a useful purpose. 


\section{REFERENCES}

Bary, A. (2005). A happy tune. Barron's, 85(6), 16-17. Retrieved from

https://search.proquest.com/docview/201043532 ?accountid=158986

Clarkson, K. W., Miller, R. L., Jentz, G., \& Cross, F. (1995). Intellectual property and computer law in West's business law (6th ed.). St. Paul, MN: West Publishing Company.

EauClaire, M. (2012, Nov). A platform for standardization of specialized equipment. OEM Off Highway, 30, 12-14,16. Retrieved from https:search.proquest.com/docview/1269473808?aacountid=158986

Harmon, A. (2003). Universal sues Bertelsmann over ties to Napster. The New York Times. Retrieved from http://www.nytimes.com/2003/05/13/business/universal-suesbertelsmann-over-ties-to-napster.html

Horgan, J. (2006, p.1). Please don't take my blackberry away- RIM vs NTP. EDACafe. Retrieved from http://www10.edacafe.com/nbc/articles/view_weekly.php?articleid=246700

Kelley, R. (2006). Blackberry maker, NTP ink $\$ 612$ million settlement. CNN. Retrieved from http://money.cnn.com/2006/03/03/technology/rimm_ntp/

Kravets, D. (2009, para.8). Dec. 7, 1999: RIAA sues Napster. Wired. Retrieved from https://www.wired.com/2009/12/1207riaa-sues-napster/

Levy, S. (2005, May 16). Thinking outside the (music) box. Newsweek, 145, 16. Retrieved from https://search.proquest.com/docview/214289192?accountid=158986

Patel, N. (2015, para.5). Metallica sued Napster 15 years ago today. The Verge. Retrieved from https://www.theverge.com/2015/4/13/8399099/metallica-sued-napster-15-years-agotoday

Popper, B. (2016, June 14). Rhapsody rebrands itself as Napster because ${ }^{-}\left\lfloor(ツ) \_/^{-}\right.$. Retrieved from https://www.theverge.com/2016/6/14/11936974/rhapsody-rebrands-as-napster

Rosoff, M. (2011). Napster is finally dead: Here's a look back at what it once meant. Business Insider. Retrieved from http://www.businessinsider.com/napster-is-finally-dead-heresa-look-back-at-what-happened-2011-10

Rowell, E. (2017). Court rules against Napster. ABC News. Retrieved from http://abcnews.go.com/Technology/story?id=98767

Sandoval, G. (2007). Bertelsmann and EMI settle Napster-related court case. CNET. Retrieved from https://www.cnet.com/news/bertelsmann-and-emi-settle-napster-related-courtcase/

Stich, G. (2017, August 3). Oxbo Wins Patent Infringement Case Against H\&S Mfg. Retrieved from https://www.farm-equipment.com/articles/14400-oxbo-wins-patent-infringementcase-against-hs-mfg

Taro, K. (2000, September 25). Meet the Napster. Retrieved from http://edition.cnn.com/ALLPOLITICS/time/2000/10/02/napster.html

Weston, D., \& Lim, K. (2008, p.3). Blackberry. In A Teaching Case for WIPO. Retrieved from http://www.wipo.int/export/sites/www/academy/en/about/global_network/educatio nal_materials/cs2_blackberry.pdf 